
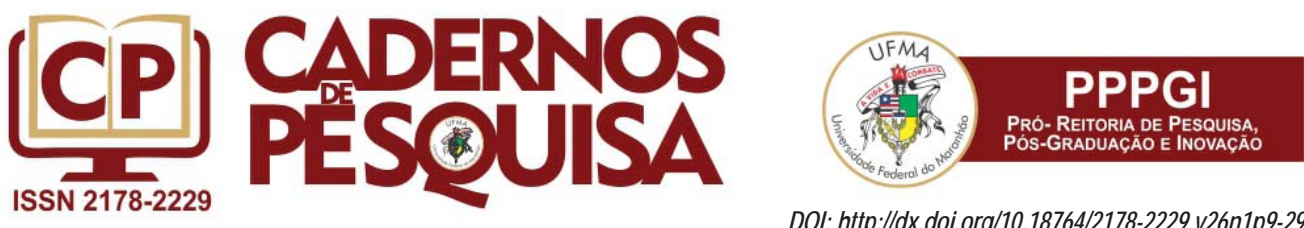

DOI: http://dx.doi.org/10.18764/2178-2229.v26n1p9-29

\title{
BASE NACIONAL COMUM CURRICULAR E A LACUNA NO ENSINO DE INGLÊS PARA CRIANÇAS NO BRASIL ${ }^{1}$
}

COMMON NATIONAL CURRICULUM BASIS AND THE GAP IN THE TEACHING ENGLISH FOR CHILDREN IN BRAZIL

\section{BASE NACIONAL COMÚN CURRICULAR Y LA AUSENCIA DE LA ENSEÑANZA DE INGLÉS PARA NIÑOS EN BRASIL}

\author{
Ana Paula de Lima \\ Doutora em Educação pela UNESP. \\ Rio Claro-SP, Brasil. \\ anapl.letras@yahoo.com.br \\ Raquel Fontes Borghi \\ Professora Doutora da UNESP. \\ Rio Claro-SP, Brasil. \\ raborghi@gmail.com \\ Samuel de Souza Neto \\ Professor Doutor da UNESP. \\ Rio Claro-SP, Brasil. \\ samuelsn@rc.unesp.br
}

\section{Resumo}

Tendo em vista a importância da Língua Inglesa nos mais diversos âmbitos da sociedade contemporânea, podemos observar uma grande expansão do ensino dessa língua estrangeira nas escolas de Educação Infantil e Anos Iniciais do Ensino Fundamental, tanto públicas quanto privadas. A falta de diretrizes oficiais nacionais que orientem a formação e o trabalho do professor, oriunda do caráter facultativo da inclusão de línguas estrangeiras na matriz curricular desses níveis de ensino, traz implicações para a qualidade do ensino de Inglês para crianças. Assim, considerando a importância de se regulamentar esse ensino, este trabalho teve por objetivos identificar e analisar, na primeira e última versões da Base Nacional Comum Curricular (BNCC), as referências ao ensino de Língua Inglesa para crianças e os encaminhamentos para o trabalho docente na Educação Infantil e no Ensino Fundamental I. Opta-se pela pesquisa qualitativa, estudo documental, considerando-se a análise documental da BNCC. A análise mostrou que os documentos não abrangem o ensino de Inglês para crianças, de forma que a lacuna na legislação vigente permanece perpetuando a forma, muitas vezes inadequada, como o ensino vem sendo incluído e conduzido nas escolas regulares brasileiras.

Palavras-chave: Ensino de Inglês. Educação Infantil. Ensino Fundamental I. Base Nacional Comum Curricular.

\begin{abstract}
In view of the importance of the English language in the most diverse areas of contemporary society we can observe a great expansion of foreign language the teaching of English in Early Childhood Education and in the initial years of Elementary School both public and private. The lack official national guidelines that orient the formation and the work of the teacher, originated from the optional nature of the inclusion of foreign languages in the curricular matrix of these levels of education, has implications for the quality of English teaching for children. Thus, considering the importance of regulating this teaching. This article aimed to identify and analyze in the first and last versions of the Common National Curricular Basis (BNCC), the references of English language for children and the referrals for teaching work in early childhood and elementary education. We opted for qualitative research, documentary study, considering the documentary analysis of BNCC. The analysis showed that the documents do not reach the teaching of English for children
\end{abstract}

\footnotetext{
O presente trabalho foi realizado com apoio de Coordenação de Aperfeiçoamento de Pessoal de Nível Superior - Brasil (CAPES) - código de financiamento 001.
} 
so that the current legislation gap continues to perpetuate the often inadequate way in which teaching has been included and conducted in Brazilian regular schools.

Keywords: English Language Teaching. Early Childhood Education. First Years of Elementary School. Common National Curricular Basis.

\section{Resumen}

Teniendo en cuenta la importancia de la Lengua Inglesa en los más distintos ámbitos de la sociedad contemporánea, podemos observar una gran expansión de la enseñanza de esa lengua extranjera en las escuelas de Educación Infantil y Años Iniciales de la Enseñanza Fundamental, tanto públicas cuánto. La falta de directrices oficiales que orienten la formación y el trabajo del profesor, originada del carácter facultativo de la inclusión de lenguas extranjeras en la matriz curricular de esos niveles de enseñanza, trae implicaciones para la calidad de la enseñanza de inglés para niños. Así, considerando la importancia de la reglamentación de ese nivel de enseñanza, este trabajo tuve por objetivos identificar y analizar, en la primera y última versiones de la Base Nacional Común Curricular (BNCC), hacen referencia a la enseñanza de Lengua inglesa para niños y los encaminamientos para el trabajo docente en la Educación Infantil y en la Enseñanza Fundamental I. Se elige por la pesquisa cualitativa, estudio documental, considerando el análisis documental de la BNCC. El análisis mostró que los documentos no abarcan la enseñanza de Inglés para niños, de modo que la ausencia en la legislación vigente continúa, perpetuando la manera, muchas veces inadecuada, de cómo la enseñanza está siendo incluida y conducida en las escuelas regulares brasileñas.

Palabra-clave: Enseñanza de Lengua Inglesa. Educación Infantil. Enseñanza Fundamental I. Base Nacional Común Curricular.

\section{INTRODUÇÃO}

Em nossa acepção, a busca por um ensino mais efetivo no contexto em questão abarca o princípio de que a criança brasileira tem o direito a uma educação de línguas que, de forma crítica, traga à sala de aula a relação entre o local e o global, tornando-a cidadã plena de um mundo plurilíngue e multicultural. (ROCHA, 2008, p. 28)

Neste artigo apresentamos um recorte de uma pesquisa de doutorado que trata da formação de professores de inglês para crianças no Brasil. Apesar de o ensino de Língua Inglesa (LI) ser obrigatório apenas a partir do Ensino Fundamental II, conforme prevê a Lei de Diretrizes e Bases da Educação Nacional (LDB) em vigência, a disciplina tem sido incluída na matriz curricular das escolas regulares brasileiras cada vez mais cedo (SCHEIFER, 2008; COSTA, 2009), tendo em vista a sua frequente utilização nos meios de comunicação, no mundo acadêmico, nas relações comerciais, dentre outros.

Dada sua importância como instrumento de comunicação global na sociedade atual (RAJAGOPALAN, 2009), a disciplina LI, que antes era um diferencial de algumas escolas particulares de Educação Infantil e Anos Iniciais do Ensino Fundamental, aos poucos, começou a ser oferecida nas escolas da rede pública brasileira, dependendo de iniciativas estaduais e municipais.

No Estado de São Paulo, por exemplo, a Secretaria da Educação implantou, no ano de 2013, a disciplina LI na matriz curricular dos alunos dos $1^{\circ}, 2^{\circ}$ e $3^{\circ}$ anos do Ensino Fundamental de 10 escolas estaduais de diferentes regiões do Estado, a ser ministrada por professor especialista, formado em Letras. No ano seguinte, segundo a Resolução SE $n^{\circ} 29 / 2014$, o número de escolas que ofereciam a referida disciplina aumentou para 56. O projeto, ainda em andamento, prevê duas aulas semanais de inglês e os professores especialistas recebem formação na Escola de Formação e Aperfeiçoamento do Professor por uma semana.

Também no ano de 2013, a prefeitura de Rio Claro/SP, cidade na qual realizamos a pesquisa de doutorado, incluiu uma hora-aula semanal de LI para os alunos dos $4^{\text {os }}$ e $5^{\text {os }}$ anos do Ensino Fundamental (RIO CLARO, 2013), sendo que, a partir do ano seguinte, a carga horária dos alunos dos $5^{\text {os }}$ anos passou para duas horas-aula semanais (RIO CLARO, 2014, 2015). 
Apesar de reconhecer que houve certo avanço na oferta dessa disciplina na Educação Infantil e, principalmente, no Ensino Fundamental I público, seu caráter facultativo traz implicações para a qualidade do ensino. Em primeiro lugar, cabe aos Estados e, principalmente, aos Municípios decidir se a LI será ou não incluída nesses níveis de ensino e, conforme apontado por Ramos (2007), poucas prefeituras assumem esse desafio, o que faz com que nem todos os alunos do setor público tenham as mesmas oportunidades de acesso à aprendizagem do inglês. Além disso, uma vez que o ensino de LI para crianças não está previsto em lei, os cursos de graduação em Letras formam professores de inglês para atuarem no Ensino Fundamental II e Médio, ou seja, não incluem, em geral, disciplinas que tratem especificamente do ensino dessa língua estrangeira na Educação Infantil e Anos Iniciais do Ensino Fundamental. Também não há parâmetros oficiais específicos que orientem o trabalho do professor de LI nesses segmentos, o que faz com que o ensino ocorra "de forma aleatória, precariamente planejada e, assim, bastante fragmentada" (SCARAMUCCI; COSTA; ROCHA, 2008, p. 85).

Mesmo sabendo da inexistência de documentos oficiais nacionais que orientem a formação e a prática pedagógica dos professores de LI para crianças, analisamos neste trabalho a primeira e a última versões da Base Nacional Comum Curricular, a fim de verificar se os documentos, recentemente publicados, fazem referência ao ensino de LI na Educação Infantil e Ensino Fundamental I.

A presente pesquisa visa responder à seguinte pergunta: A primeira e a última versões da Base Nacional Comum Curricular apontam encaminhamentos para o desenvolvimento do trabalho docente com a LI na Educação Infantil e Ensino Fundamental I?

O objetivo do trabalho foi identificar e analisar se as duas versões da Base Nacional Comum Curricular fazem referência ao ensino de LI para crianças. Portanto, o que se busca é identificar se os referidos documentos trazem diretrizes que orientem o trabalho docente na Educação Infantil e no Ensino Fundamental I.

Esse trabalho se justifica pela grande expansão do ensino de LI para crianças no contexto educacional brasileiro que, na ausência de diretrizes oficiais, tem ocorrido de forma aleatória. Sem formação específica para ensinar LI para crianças e sem parâmetros que orientem o trabalho em sala de aula, os professores tendem a conduzir o ensino da forma como julgam mais adequada e a aprendizagem da docência acaba ocorrendo por meio da tentativa-erro, retrocedendo ao que Gauthier et al. (1998) denominam de "um ofício sem saberes." Além disso, retomando a citação de Rocha (2008, p. 28), com a qual iniciamos este artigo, o ensino de LI não tem como objetivo apenas instrumentalizar a criança para sua futura inserção no mercado de trabalho, mas sim torná-la "cidadã plena de um mundo plurilíngue e multicultural." De acordo com Goergen (2013, p. 732):

\footnotetext{
Para que o direito seja atendido, isto é, para que o sujeito possa se tornar cidadão, é necessário habilitá-lo à convivência social. Isto, por sua vez, exige a capacidade de expressar seus ideais, interesses e necessidades e defender seus direitos no espaço público. Precisa, além disso, ter condições de participar de todo o processo social que Ihe garanta a vida digna, em termos de trabalho e emprego para a sua sobrevivência em condições dignas. Ou, para dizê-lo de outra maneira, ele precisa ter condições de acesso aos bens materiais e culturais produzidos pela sociedade. Para que isso seja possível, é necessário desenvolver suas potencialidades de domínio dos conhecimentos e habilidades, bem como o manejo dos códigos de comunicação indispensáveis à argumentação.
}

O autor ressalta que, apesar de existirem múltiplos caminhos para a aquisição dessas capacidades e habilidades, o principal deles continua a ser a educação formal, que promove "o comportamento reflexivo-crítico indispensável à cidadania ativa, com identidade e pertinência, visando um projeto coletivo de convivência verdadeiramente democrático" (GOERGEN, 2013, p. 734). Goergen (2013) também aponta a necessidade 
de se repensar a educação formal no que se refere aos procedimentos pedagógicos, aos conteúdos e a proposta de formação cidadã, tendo em vista a realidade complexa, plural, fluente, globalizada e multicultural na qual vivemos.

Feitas essas colocações, acreditamos que o ensino de LI, desde o início da vida escolar, pode, de fato, contribuir para a formação cidadã dos alunos brasileiros, tendo em vista a importância dessa língua para o acesso à informação e para a própria ação dos indivíduos na sociedade atual.

Nesse sentido, além de verificar a inclusão da LI no documento oficial mais recente, que estabelece o currículo mínimo das escolas de Educação Infantil e Ensino Fundamental I, este trabalho visa atentar para a necessidade de regulação do ensino de LI para crianças no Brasil, bem como sobre a necessidade de rever o currículo dos cursos de formação de professores de inglês.

\section{PROCEDIMENTOS METODOLÓGICOS}

Opta-se pela pesquisa qualitativa, estudo documental, considerando-se os documentos da Base Nacional Comum Curricular (primeira versão e terceira versão) e a análise de conteúdo. Na compreensão de Silva et al. (2009), o documento - como produto de uma sociedade - manifesta o jogo de força dos que detêm o poder. Portanto, não são produções isentas, ingênuas, mas elas traduzem leituras e modos de interpretação do vivido por um determinado grupo de pessoas em um dado tempo e espaço (LE GOFF, 1996, p. 536).

Para Bravo (1991), todas as realizações produzidas pelo homem são documentos que se mostram como indícios de sua ação e que podem revelar suas ideias, opiniões e formas de atuar e viver. Nessa concepção é possível apontar vários tipos de documentos: os escritos; os numéricos ou estatísticos; os de reprodução de som e imagem; e os documentos-objeto. Porém, Calado e Ferreira (2004, p. 3) consideram que...

\footnotetext{
Os documentos são fontes de dados brutos para o investigador e a sua análise implica um conjunto de transformações, operações e verificações realizadas a partir dos mesmos com a finalidade de se lhes ser atribuído um significado relevante em relação a um problema de investigação.
}

Dessa forma, Silva et al. (2009) consideram a pesquisa documental não como uma técnica ou procedimento de coleta de dados, mas sim como um método de pesquisa, pois o trabalho com os documentos é compreendido em dois momentos distintos: o primeiro, de coleta de documentos; o segundo, de análise do conteúdo. Assim, Bravo (1991, p. 288) define que "las unidades de análisis em análisis de contenido son modalidades especiales y particularizadas de las unidades de obervación", as quais são eleitas pelo pesquisador e se apresentam em modalidades fundamentais, quais sejam: as de registro e as de contexto. Já as unidades de contexto dizem respeito à compreensão do contexto da qual faz parte a mensagem que está sendo analisada (GOMES, 2007). Bravo (1991) complementa anunciando que elas são formadas por partes ou segmentos do conteúdo necessários a compreensão do significado das unidades de registro, podem ser o parágrafo, o capítulo ou o documento inteiro. $\mathrm{Na}$ concepção de Gomes (2007, p. 87), as unidades de registro são as que "se referem aos elementos obtidos através da decomposição do conjunto da mensagem." Nesta direção, Bravo (1991) as compreendem como unidades de sentido localizadas no texto, dele extraídas e codificadas, expressando-se por meio de palavras, concepções, afirmações e temas.

Portanto, para um trabalho de análise de conteúdo relevante e consistente, destaca-se a importância da leitura compreensiva do material de forma exaustiva, para que sejam bem escolhidas e definidas as unidades de análise e as categorias a serem consideradas, uma vez que estas já se constituem em uma espécie de conclusão da análise (SILVA et al., 2009). 
3 TRAJETÓRIA DO ENSINO DE LI NO BRASIL: do Regime Imperial à elaboração da Base Nacional Comum Curricular

Com o intuito de verificar se a Base Nacional Comum Curricular faz referência ao ensino de LI para crianças, que apesar de facultativo já é uma realidade no contexto educacional brasileiro, tanto público quanto privado, apresentamos nossa análise da primeira e da última versões do referido documento.

Para melhor compreensão da proposta, julgamos importante apresentar, inicialmente, um breve histórico do ensino de línguas estrangeiras no Brasil, especificamente da LI. Para apresentar essa trajetória, baseamo-nos nos trabalhos de Leffa (1998), Vidotti (2012) e Gileno (2013) e, quando possível, recorremos às leis por eles mencionadas.

\title{
3.1 O ensino de LI no Brasil
}

O ensino de LI institucionaliza-se no Brasil por meio da Decisão $n^{\circ} 29$, de 14 de julho de 1809 , assinada pelo Príncipe Regente D. João. O referido documento previa a nomeação de um professor de inglês e de um professor de francês para lecionar no Rio de Janeiro:

\begin{abstract}
E sendo outrossim tão geral, e notoriamente conhecida a necessidade, e utilidade das línguas franceza e ingleza, como aquellas que entre as linguas vivas teem o mais distinto logar, é de muito grande utilidade ao Estado, para augmento, e prosperidadde da instrucção pública, que se crêe nesta capital uma cadeira de lingua franceza, e outra de ingleza. (CLIB, 1809 apud VIDOTTI, 2012).
\end{abstract}

Esse trecho do documento justifica o ensino de LI no Brasil, em função de sua necessidade e utilidade. Segundo Gileno (2013), com a abertura dos portos brasileiros aos navios ingleses após a vinda da Família Real para o Rio de Janeiro, em 1808, a LI adquiriu um caráter prático, sendo um instrumento de comunicação nas relações comerciais entre Brasil e Inglaterra. Além disso, embora não fosse obrigatório, o conhecimento da LI era recomendado para a admissão nos cursos superiores, fato que, de acordo com Vidotti (2012), pode ter influenciado significativamente a regulamentação do ensino dessa língua estrangeira no Brasil. Porém, a Decisão $n^{\circ} 29$ também traz algumas diretrizes para o ensino de LI: "No ensino das duas línguas referidas seguirão os Professores quanto ao tempo, e as horas das lições, e attestações do aproveitamento dos discipulos, o mesmo que se acha estabelecido, e praticado pelos professores de Grammatica Latina" (CLIB, 1809 apud VIDOTTI, 2012).

O documento determinava que a metodologia de ensino do inglês e do francês fosse a mesma empregada para o ensino de latim, ou seja, as línguas deveriam ser ensinadas por meio de traduções de textos e análises gramaticais (método da gramáticatradução).

A LI foi incluída no currículo obrigatório das escolas 28 anos mais tarde, com a inauguração do Colégio Pedro II, por meio do Decreto de 2 de dezembro de 1837. O Colégio Pedro II foi a primeira instituição de ensino secundário criada na corte e mantida pelo governo para servir como modelo para nortear a iniciativa das províncias (VIDOTTI, 2012; GILENO, 2013) e previa o ensino da LI no seu Artigo $3^{\circ}$ :

Art. $3^{\circ}$ Neste collegio serão ensinadas as linguas latina, grega, franceza e ingleza; rhetorica e os principios elementares de geographia, historia, philosophia, zoologia, meneralogia, botanica, chimica, physica, arithmetica, algebra, geometria e astronomia. (CLIB, 1837 apud VIDOTTI, 2012).

Apesar da inclusão do inglês e do francês nos currículos escolares, o estudo das línguas clássicas era, num primeiro momento, privilegiado, conforme apontado por Chagas (1967 apud GILENO, 2013, p. 17): 
Não só o latim, mas também o grego - as chamadas "línguas clássicas" - foram por muito tempo as mais prestigiadas nos vários currículos do Colégio Pedro II, e em segundo lugar, figuravam as línguas modernas (francês e inglês). Dentre as reformas curriculares, destacam-se a de 1841 - que introduz o estudo do alemão como língua obrigatória, ao lado do francês e do inglês, e a de 1855, a Reforma Couto Ferraz, que aumentou o número de anos de estudos das línguas modernas que, pela primeira vez, ganharam destaque nos currículos escolares, à semelhança das línguas clássicas. Em 1857, os estudos das línguas modernas, compreendendo os estudos de francês (três anos), inglês (quatro anos) e alemão (dois anos) e o estudo facultativo de italiano (um ano), perfaziam um total de nove anos o que equivalia aos estudos obrigatórios das línguas clássicas: sete anos de latim e dois anos de grego.

Nesse sentido, até o fim do regime imperial, o equilíbrio entre o estudo das línguas clássicas e modernas permaneceu estável, no entanto, reduziu-se, gradualmente, o número de anos de estudo das mesmas. Em 1881, passou-se a estudar quatro anos de latim, dois anos de grego, dois de inglês, dois de francês, dois de alemão e um ano facultativo de italiano, com uma média de 3 horas semanais tanto para as línguas clássicas como para as línguas modernas.

O trabalho de Gileno (2013), também, permite-nos compreender a trajetória do ensino de línguas no Brasil, durante o regime imperial, especialmente no que se refere à carga horária destinada ao ensino das diferentes línguas estrangeiras que compunham o currículo escolar. A autora enfatiza, ainda, que continuava a não haver orientações específicas para o ensino das línguas vivas, que eram ensinadas através do método da gramática-tradução, assim como era conduzido o estudo das línguas mortas.

De acordo com a autora, o período de 1890 a 1930 também é marcado por um gradual declínio do ensino de línguas estrangeiras, que tem o seu total de horas reduzido pela metade. Apenas em 1931, com a Reforma Francisco de Campos, as línguas estrangeiras modernas passaram a ser mais privilegiadas do que as línguas clássicas, tendo em vista que, no ciclo fundamental, os anos de estudo de latim são reduzidos para duas séries, enquanto eram previstas quatro séries de estudo de francês, três séries de estudo de inglês, além do estudo facultativo do alemão.

Art. $3^{\circ}$ Constituirão o curso fundamental as disciplinas abaixo indicadas, distribuídas em cinco anos, de acordo com a seguinte seriação:

$1^{a}$ série: Português - Francês - História da Civilização - Geografia - Matemática Ciências físicas e naturais - Desenho - Música (canto orfeônico).

$2^{a}$ série: Português - Francês - Inglês - História da Civilização - Geografia - Matemática - Ciências físicas e naturais - Desenho - Música (canto orfeônico).

$3^{a}$ série: Português - Francês - Inglês - História da Civilização - Geografia - Matemática - Física - Química - História Natural - Desenho - Música (canto orfeônico).

$4^{a}$ série: Português - Francês - Inglês - Latim - Alemão (facultativo) - História da Civilização - Geografia - Matemática - Física - Química - Historia Natural - Desenho.

$5^{a}$ série: Português - Latim - Alemão (facultativo) - História da Civilização - Geografia - Matemática - Física - Química - Historia Natural - Desenho. (BRASIL, 1932, grifo nosso).

No ciclo complementar, os alunos poderiam estudar mais duas séries de inglês ou alemão (candidatos dos cursos de medicina, farmácia ou odontologia) ou de latim (candidatos do curso jurídico):

Art. $4^{\circ} \mathrm{O}$ curso complementar obrigatório para os candidatos à matrícula em determinados institutos de ensino superior, será feito em dois anos de estudo intensivo, com exercícios e trabalhos práticos individuais, e compreenderá as seguintes disciplinas: Alemão ou Inglês, Latim, Literatura, Geografia, Geofísica e Cosmografia, História da Civilização, Matemática, Física, Química, História Natural, Biologia Geral, 
Higiene, Psicologia e Lógica, Sociologia, Noções de Economia e Estatística, História da Filosofia e Desenho.

Art. $5^{\circ}$ Para os candidatos à matrícula no curso jurídico são disciplinas obrigatórias:

$1^{a}$ série: Latim - Literatura - História da Civilização - Noções de Economia e Estatística - Biologia Geral - Psicologia e Lógica.

$2^{\mathrm{a}}$ série: Latim - Literatura - Geografia - Higiene - Sociologia - História da Filosofia.

Art. $6^{\circ}$ Para os candidatos à matrícula nos cursos de medicina, farmácia e odontologia são disciplinas obrigatórias:

$1^{a}$ série: Alemão ou Inglês - Matemática - Física - Química - História Natural - Psicologia e Lógica.

$2^{\mathrm{a}}$ série: Alemão ou Inglês - Física - Química - História Natural - Sociologia - Desenho. (BRASIL, 1932, grifo nosso).

Nesse período, Gileno (2013) ressalta que o método direto indutivo, que previa o ensino da língua estrangeira na própria língua estrangeira, era o método oficial. Embora o papel do aluno nesse método seja menos passivo do que no método da gramáticatradução, o ensino continuava centrado no professor.

O ensino de línguas estrangeiras, tanto clássicas quanto modernas, foi privilegiado a partir da Reforma Capanema, de 1942, conforme apontado por Gileno (2013), tanto que os anos 40 e 50 foram considerados os "anos dourados das línguas estrangeiras no Brasil” (LEFFA, 1998, p. 19). Nesse período, recomendava-se o método direto e o ensino previa não só o desenvolvimento das quatro habilidades, mas envolvia também objetivos educativos e culturais (GILENO, 2013).

A não obrigatoriedade do estudo das línguas estrangeiras, que passaram a ser consideradas "disciplinas complementares" ou "optativas" a partir da LDB de 1961 (Lei $n^{\circ}$ 4024), levou à redução de seu estudo (GILENO, 2013). Além disso, Leffa (1998) afirma que a década de 60 , apesar de representar a supremacia do inglês como língua estrangeira, marca o fim dos "anos dourados" do ensino de línguas estrangeiras em nosso país, tanto no que se refere à variedade de línguas oferecidas, quanto ao tempo de estudo, uma vez que a carga horária nesse período representa menos de $2 / 3$ do previsto na Reforma Capanema.

Dez anos depois, a Lei $n^{\circ} 5692 / 71$ reduziu um ano de escolaridade e introduziu a obrigatoriedade da habilitação profissional, reduzindo ainda mais a carga horária destinada ao ensino de línguas estrangeiras. No mesmo ano, o Parecer $n^{\circ} 853 / 71$ recomendou que a língua estrangeira fosse incluída dentro das condições de cada estabelecimento, de forma que muitas escolas retiraram a disciplina da grade curricular.

De acordo com Gileno (2013), tanto na LDB de 1961 quanto na de 1971, previa-se a utilização de métodos diversos para o ensino de línguas estrangeiras, tendo em vista as especificidades de cada região brasileira.

Em 1976, com a Resolução n58/76, o ensino de língua estrangeira voltou a ser obrigatório no $2^{\circ}$ grau, e, apenas em 1996, com a regulamentação das novas diretrizes para a educação (Lei n 9394/96), a obrigatoriedade do ensino se estende para o $1^{\circ} \mathrm{grau}$, conforme podemos observar no $\S 5^{\circ}$ do Artigo $26^{\circ}$ : "Na parte diversificada do currículo será incluído, obrigatoriamente, a partir da quinta série, o ensino de pelo menos uma língua estrangeira moderna, cuja escolha ficará a cargo da comunidade escolar, dentro das possibilidades da instituição" (BRASIL, 1996).

De acordo com o trecho citado, a escolha da língua estrangeira a ser ensinada fica a cargo da comunidade escolar, não se restringindo, portanto, à LI. Nesse sentido, Leffa (2001) esclarece que fatores políticos e econômicos influenciam a decisão, sendo a LI muitas vezes escolhida em função de seu caráter multinacional. 
A frequente utilização do inglês nos mais diferentes âmbitos da sociedade contemporânea, faz com que a LI passe a ser tratada como uma língua franca que, segundo Rajagopalan (2009), apresenta uma natureza híbrida, em constante transformação, que pertence a todos que a falam. No mesmo sentido, Lopes (2008) define o inglês como uma língua de fronteira, que permite que as pessoas se apropriem de discursos globais e reinventem a vida local em suas performances cotidianas. De acordo com Lopes (2005, p. 2):

\begin{abstract}
Em um mundo cada vez mais dividido entre aqueles que têm acesso à informação e a conhecimento em escala mundial, e, portanto, a maiores oportunidades de aprender, e aqueles que vivem limitados a informações e conhecimentos locais, e, portanto, a menores chances de ampliar seus horizontes, a aprendizagem de inglês se transformou em um dos instrumentos centrais da educação contemporânea. É um dos bens simbólicos mais valorizados no Brasil e em grande parte do mundo, tendo em vista o papel que tal língua desempenha como meio de comunicação planetário.
\end{abstract}

Feitas essas considerações, podemos afirmar que, apesar da possibilidade de escolha da língua estrangeira a ser ensinada, a LI parece ser a que mais ganha destaque no contexto educacional brasileiro. Além disso, considerando o inglês como língua franca, ou língua de fronteira, que permite a comunicação entre diferentes povos, bem como a participação ativa dos cidadãos na sociedade em que vivem, é preciso repensar o ensino de LI nas escolas regulares.

A LDB de 1996 considera que não há um único método eficaz para o ensino de língua estrangeira, entretanto, reconhece a necessidade de se estabelecer diretrizes que assegurem uma formação básica comum. Nesse sentido, em 1998, são publicados os Parâmetros Curriculares Nacionais que, no que concerne o ensino de língua estrangeira, sugerem a adoção de uma abordagem sociointeracional (GILENO, 2013).

Os Parâmetros Curriculares Nacionais não fazem referência ao ensino de línguas estrangeiras no Ensino Fundamental I, tendo em vista sua não obrigatoriedade nesse nível de ensino. Da mesma forma, as Diretrizes Curriculares Nacionais para a Educação Infantil (BRASIL, 2010), não tratam do referido ensino.

Entretanto, considerando o aumento do número de crianças aprendendo inglês nas escolas regulares (LINGUEVIS, 2007; TONELLI; CRISTOVÂO, 2010), tanto públicas quanto privadas, bem como a importância dessa língua para a comunicação e para o acesso à informação na sociedade atual (ROCHA, 2007, 2008; SCARAMUCCI; COSTA; ROCHA, 2008), propomo-nos a analisar a Base Nacional Comum Curricular, a fim de verificar se há alguma consideração acerca do ensino de inglês na Educação Infantil e Anos Iniciais do Ensino Fundamental.

\title{
3.2 0 ensino de língua estrangeira moderna na primeira versão da Base Nacional Comum Curricular
}

De acordo com informações disponíveis no site do Ministério da Educação MEC)², no ano de 2015, foi realizado o I Seminário Interinstitucional para a elaboração da Base Nacional Comum Curricular e foi instituída, por meio da Portaria $n^{\circ} 592$, uma Comissão de Especialistas para a elaboração da proposta.

No período de outubro de 2015 a março de 2016, foi realizada consulta pública para construção da primeira versão do documento, que foi finalizada em março de 2016 (BRASIL, 2017). Em junho do mesmo ano, começa-se a debater a segunda versão e, em agosto, começa a ser redigida a última versão da Base Nacional Comum Curricular.

Ao analisar a primeira versão do documento, disponibilizada no site do MEC, observamos que não há referência direta ao ensino de línguas estrangeiras na Educação Infantil.

$\operatorname{Brasil}([201-] b)$. 
O currículo desse nível de ensino está organizado em Campos de Experiências, que "incluem determinadas práticas sociais e culturais de uma comunidade e as múltiplas linguagens simbólicas que nelas estão presentes" (BRASIL, [201-]a, p. 20), que, de acordo com o documento, privilegiam as interações e brincadeiras. São cinco os Campos de Experiência, a saber: O eu, o outro e o nós; Corpo, gestos e movimentos; Fala, pensamento e imaginação; Traços, sons, cores e imagens; e Espaços, tempos, quantidades, relações e transformações.

Apesar de não incluir a língua estrangeira no currículo da Educação Infantil, consideramos que, tendo em vista o papel da LI na sociedade globalizada, seu ensino poderia contribuir para atingir alguns dos objetivos previstos para esse nível de ensino, como o desenvolvimento de uma visão plural de mundo, que respeite as diversidades culturais, bem como garantir o direito das crianças de terem acesso a "processos de apropriação, de renovação e de articulação de saberes e conhecimentos, como requisito para a formação humana, para a participação social e para a cidadania" (BRASIL, [201-] a, p. 18).

No Ensino Fundamental e Médio, o ensino de língua estrangeira moderna está previsto dentro da área de Linguagens. De acordo com o documento:

\begin{abstract}
A participação em um mundo ampliado pelo acesso às tecnologias contemporâneas, as características multiculturais do Brasil e os contatos crescentes com pessoas de outras formações socioculturais e nacionalidades requer o conhecimento de diferentes idiomas. Cabe à área de Linguagens oferecer oportunidades de vivências significativas com culturas e línguas adicionais e conhecimentos necessários, para que os/as estudantes possam se envolver em interações com textos em outra(s) língua(s) e, gradativamente, integrar-se em realidades marcadas pelo plurilinguismo e pela diversidade. (BRASIL, [201-]a, p. 30).
\end{abstract}

A Base Nacional Comum Curricular apresenta os objetivos gerais para a área de Linguagens na Educação Básica e para o Ensino Fundamental e Médio, especificamente. Um dos objetivos gerais da área para o Ensino Fundamental prevê o reconhecimento e a compreensão do uso de outra(s) línguas(s), bem como a valorização de diferentes culturas, entretanto, não há referência específica ao ensino de LI nos anos iniciais do Ensino Fundamental.

Ao apresentar o Componente Curricular Língua Estrangeira Moderna, que integra a área de Linguagens juntamente com Língua Portuguesa, Arte e Educação Física, o documento reforça os objetivos do ensino de língua estrangeira do Ensino Fundamental:

O compromisso do componente consiste em oferecer aos/às estudantes condições e conhecimentos necessários para vivenciarem situações que envolvam textos na(s) língua(s) em estudo, relevantes às suas vidas e à interação com pessoas de outras formações socioculturais e nacionalidades, tendo em vista a participação em um mundo ampliado pelos diversos fluxos e tecnologias contemporâneos. A atuação em espaços (presenciais e virtuais) que acontecem nessa(s) língua(s) cria oportunidades para que o/a estudante possa perceber-se parte integrante e ativa de um mundo plurilíngue, em que realidades se constroem pelo uso de múltiplas linguagens e por fronteiras difusas, considerando o acesso ampliado, pelos meios digitais, a cenários que se dão em várias línguas. (BRASIL, [201-]a, p. 67).

Como o documento apresenta os objetivos do ensino de língua estrangeira no Ensino Fundamental de maneira geral, sem fazer distinção entre os anos iniciais e finais, poderíamos compreender que o texto se refere tanto ao Ensino Fundamental I quanto ao Ensino Fundamental II, assim como acontece nos demais componentes curriculares da área de Linguagens. Entretanto, ao explicitar os objetivos de aprendizagem da Língua Estrangeira Moderna, o documento inicia pelo $6^{\circ}$ ano do Ensino Fundamental, ao contrário da Língua Portuguesa, Artes e Educação Física, que apresentam os objetivos a partir do $1^{\circ}$ ano do Ensino Fundamental. 
O documento também apresenta alguns desafios que o Componente Curricular Língua Estrangeira Moderna precisa enfrentar, como a visão tecnicista de língua, as condições de trabalho adversas e a própria escolha da língua a ser ensinada. Entretanto, não há, entre os desafios apontados no documento, nenhuma referência à inclusão da língua estrangeira na matriz curricular da Educação Infantil e Ensino Fundamental I, fato que nos chama a atenção, tendo em vista que a expansão do ensino da LI nesses níveis de ensino, na ausência de diretrizes que orientem o trabalho e a formação docente, tem ocorrido de forma aleatória e em uma atmosfera bastante conflituosa (ROCHA, 2008), onde, muitas vezes, não há consonância entre os objetivos da escola, dos professores, dos pais e dos próprios alunos (LIMA, 2004).

\subsection{O ensino de LI na terceira versão da Base Nacional Comum Curricular}

No ano de 2017, o Ministério da Educação (MEC) entregou ao Conselho Nacional de Educação a versão final da Base Nacional Comum Curricular para apreciação. $O$ documento atual apresenta os direitos e objetivos de aprendizagem e desenvolvimento para os alunos da Educação Básica (BRASIL, 2017, p. 5), mas não contempla mais o Ensino Médio.

Ao analisar a última versão do documento, observamos que não foi acrescentada nenhuma discussão acerca do ensino de LI para crianças da Educação Infantil e dos anos iniciais do Ensino Fundamental. Apesar de sofrer algumas alterações, o currículo da Educação Infantil mantém-se organizado em Campos de Experiências, privilegiando as interações e brincadeiras. No que se refere aos objetivos previstos para esse nível de ensino na versão mais atual do documento, consideramos que o ensino de LI poderia contribuir, no sentido de ampliar "o universo de experiências, conhecimentos e habilidades dessas crianças, diversificando e consolidando novas aprendizagens (...)" (BRASIL, 2017, p. 32), bem como para garantir os direitos de aprendizagem e desenvolvimento das crianças, apresentados e discutidos no documento: Conviver, Brincar, Participar, Expressar e Conhecer-se.

No Ensino Fundamental, o ensino de LI está previsto dentro da área de Linguagens, entretanto, apenas para alunos dos anos finais, conforme pode-se observar na figura abaixo:

Figura 1 - Áreas do conhecimento que compõem o Ensino Fundamental.

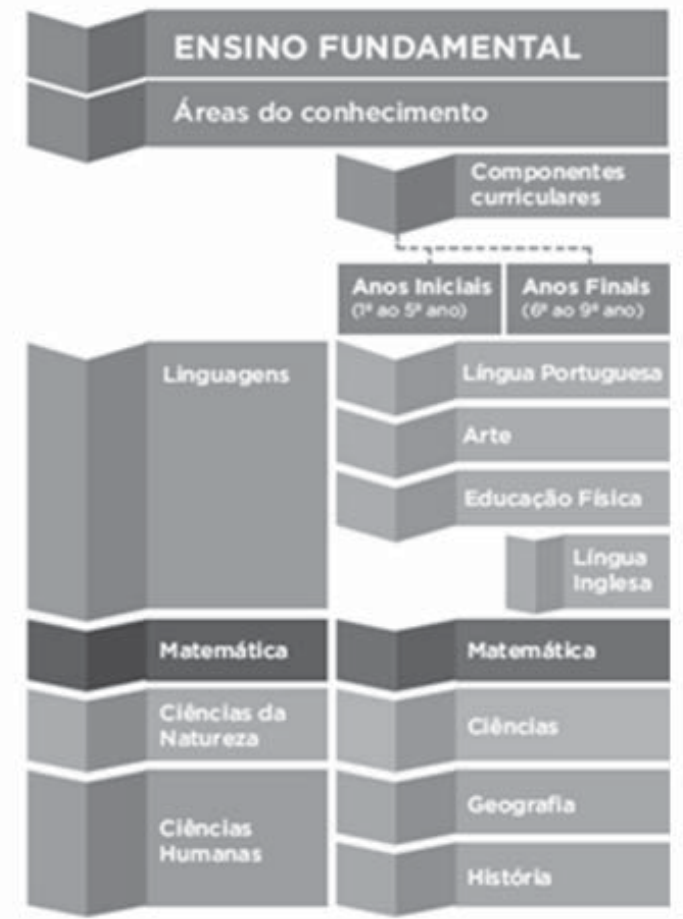


De acordo com o documento:

Por sua vez, no Ensino Fundamental-Anos Finais, as aprendizagens, nos componentes curriculares da área de Linguagens, ampliam as práticas de linguagem conquistadas no Ensino Fundamental - Anos Iniciais, incluindo a aprendizagem de Língua Inglesa, para expandir os repertórios dos estudantes, intensificar a diversificação dos contextos e adensar a análise de como as práticas artísticas, corporais e linguísticas se constituem e constituem a vida social. (BRASIL, 2017, p. 61, grifo nosso).

No trecho acima, a inclusão da LI nos Anos Finais do Ensino Fundamental é considerada uma forma de ampliar as práticas de linguagem desenvolvidas nos níveis de ensino anteriores. Entretanto, desconsidera-se o contato formal dos estudantes com a LI nas escolas regulares de Educação Infantil e Ensino Fundamental I, que já é realidade em muitas escolas públicas e privadas de nosso país (PIRES, 2004; ROCHA, 2006; LINGUEVIS, 2007; SCARAMUCCI; COSTA; ROCHA, 2008; TONELLI; CRISTOVÃO, 2010; dentre outros).

Tendo em vista as características da sociedade atual, cada vez mais globalizada e plural, a Base Nacional Comum Curricular apresenta os objetivos gerais do ensino de LI:

Assim, o estudo da língua inglesa possibilita aos alunos ampliar horizontes de comunicação e de intercâmbio cultural, científico e acadêmico e, nesse sentido, abre novos percursos de acesso, construção de conhecimentos e participação social. É esse caráter formativo que inscreve a aprendizagem de inglês em uma perspectiva de educação linguística, consciente e crítica, na qual as dimensões pedagógicas e políticas são intrinsecamente ligadas. (BRASIL, 2017, p. 199).

A partir desses objetivos, são apresentadas duas implicações importantes para - currículo: a necessidade de se propiciar uma educação linguística voltada para a interculturalidade e de se ampliar a visão de letramentos.

O documento ressalta a visão da LI como língua franca, língua de comunicação internacional, falada não só por nativos, mas por pessoas do mundo todo, com repertórios culturais e linguísticos diversos. Nesse sentido, as aulas de LI não devem se limitar aos padrões de alguns países que têm a LI como língua oficial, mas propiciar práticas interculturais que permitam aos alunos reconhecerem e respeitarem as diferenças.

Além disso, a Base Nacional Comum Curricular reconhece que a LI potencializa a participação ativa nas práticas sociais digitais, que envolvem diferentes semioses e linguagens. Dessa forma, o trabalho com múltiplos letramentos faz-se importante nas salas de aula.

Essas duas implicações embasam os eixos organizadores propostos para o ensino da LI e as competências específicas que se visa desenvolver a partir do ensino dessa Língua Estrangeira no Ensino Fundamental, a saber:

1. Identificar o lugar de si e o do outro em um mundo plurilíngue e multicultural, refletindo, criticamente, sobre como a aprendizagem da língua inglesa contribui para a inserção dos sujeitos no mundo globalizado, inclusive no que concerne ao mundo do trabalho.

2. Comunicar-se na língua inglesa, por meio do uso variado de linguagens em mídias impressas ou digitais, reconhecendo-a como ferramenta de acesso ao conhecimento, de ampliação das perspectivas e de possibilidades para a compreensão dos valores e interesses de outras culturas e para o exercício do protagonismo social.

3. Identificar similaridades e diferenças entre a língua inglesa e a língua materna/ outras línguas, articulando-as a aspectos sociais, culturais e identitários, em uma relação intrínseca entre língua, cultura e identidade.

Cad. Pesq., São Luís, v. 26, n. 1, p. 9-29, jan./mar., 2019. 
4. Elaborar repertórios linguístico-discursivos da língua inglesa, usados em diferentes países e por grupos sociais distintos dentro de um mesmo país, de modo a reconhecer a diversidade linguística como direito e valorizar os usos heterogêneos, híbridos e multimodais emergentes nas sociedades contemporâneas.

5. Utilizar novas tecnologias, com novas linguagens e modos de interação, para pesquisar, selecionar, compartilhar, posicionar-se e produzir sentidos em práticas de letramento na língua inglesa, de forma ética, crítica e responsável.

6. Conhecer diferentes patrimônios culturais, materiais e imateriais, difundidos na língua inglesa, com vistas ao exercício da fruição e da ampliação de perspectivas no contato com diferentes manifestações artístico-culturais. (BRASIL, 2017, p. 202).

Consideramos que esses objetivos são muito importantes para a condução do ensino de LI no Ensino Fundamental, tendo em vista a aprendizagem da LI para uma atuação crítica e consciente no mundo (real e virtual).

Entendemos que a não obrigatoriedade do ensino de línguas estrangeiras antes do Ensino Fundamental II, de certa forma, justifique sua ausência no documento. Entretanto, consideramos que, ao não mencionar o ensino de LI nas escolas de Educação Infantil e Ensino Fundamental I, a forma, muitas vezes inadequada, como o ensino vem sendo incluído e conduzido nesses níveis de ensino nas escolas regulares brasileiras, perpetua-se.

4 A TÍTULO DE ENCAMINHAMENTO E CONCLUSÃO: algumas considerações sobre os desafios a serem enfrentados no Ensino de LI na Educação Infantil e no Ensino Fundamental I

Nóvoa (1999, p. 13) aponta que nos programas de ação política, discursos reformadores, documentos dos "especialistas" ou na literatura produzida pelos investigadores, as palavras de ordem chamam a atenção sobre a importância dos professores nos "desafios do futuro", mas que esse excesso de discursos acaba escondendo também uma pobreza das práticas políticas. Algo que, a nosso ver, coadunase muito bem com o que está sendo feito com a Base Nacional Comum Curricular.

Assim sendo, na forma de encaminhamentos de discussões futuras, bem como conclusão deste texto, apresentamos algumas considerações que não podem ser ignoradas, organizadas de acordo com os seguintes temas: das línguas modernas e clássicas do passado às línguas estrangeiras do presente no currículo: um descompasso; de um ofício sem saberes à perspectiva de um ofício feito de saberes; e, a Base Nacional Comum Curricular como proposta para o século XXI.

\subsection{Das línguas modernas e clássicas do passado às línguas estrangeiras do presente no currículo: um descompasso}

Decorrente dos ideais do iluminismo, o currículo enciclopédico marcou época no século XIX, no Brasil, vinculado ao processo de escolarização em que as chamadas "línguas clássicas" - latim e grego - faziam parte do currículo do Colégio Pedro II, tendo introduzido posteriormente as línguas modernas - francês, inglês e alemão - no ensino primário.

Porém, no século XX, há alterações a partir das Leis de Diretrizes e Bases (BRASIL, 1961, 1971a, 1996), ficando no currículo escolar, inicialmente, o francês e, posteriormente, o inglês a partir do Ensino Fundamental II.

Nesse período, o tratamento dado ao ensino de línguas estrangeiras, vai de uma compreensão de prática educativa na década de 60 , passando pela ideia de atividade ou área de estudo nos anos 70, chegando a compreensão de disciplina nos anos 90, para entrar no século XXI como uma disciplina que pode fazer parte do currículo no Ensino Fundamental II, mas cuja avaliação final não significa retenção. Cabe colocar 
que o mesmo tratamento foi dado para as disciplinas de Educação Artística e Educação Física.

No que diz respeito às orientações oficiais, cabe colocar que, na segunda metade do século XX, vamos ter, inicialmente, a partir dos anos 70, o Guia Curricular vinculado a cada disciplina/atividade/área de estudo; depois os Parâmetros Curriculares Nacionais nos anos 90; e, no início do século XXI, a proposta da Base Nacional Comum Curricular. Portanto, o que muda?

Se com o Guia Curricular e com os Parâmetros Curriculares Nacionais a preocupação ficava centralizada em produzir a disciplina de LI, desenvolvimento disciplinar, ignorava-se, na visão de Nóvoa (1992), o desenvolvimento pessoal, produzir a vida do professor; o desenvolvimento profissional, produzir a profissão docente; e, o desenvolvimento organizacional, produzir a escola. Agora, o desafio lançado para o processo formativo, com a Base Nacional Comum Curricular, se traduz em trabalhar o quadrado do desenvolvimento disciplinar, desenvolvimento pessoal, desenvolvimento profissional e desenvolvimento organizacional de forma integrada. De modo que a ideia não deixa de ser um avanço, podendo mudar substancialmente tanto a educação na escola quanto o processo de universitarização na formação de professores.

Entretanto, a partir do momento que o ensino de LI na Educação Infantil e no Ensino Fundamental I não entra formalmente no rol das prioridades, o que se tem é um grande descompasso. Esse descompasso pode ser visto por ocasião do Programa Brasil Sem Fronteiras no que diz respeito a LI, no intercâmbio de universitários em outros países, quando se falava que o domínio da língua por parte dos estudantes brasileiros, salvo as exceções, era deficitário, quando não muito fraco.

Portanto, o ideal do iluminismo em desenvolver uma formação cultural na modernidade, levando a uma autoformação, no sentido de se formar o indivíduo superior, acaba naufragando na perspectiva de uma semiformação (MITROVITCH, 2011) em tempos de modernidade líquida (BAUMAN, 2007). De modo que o ensino de LI para a Educação Infantil e o Ensino Fundamental I pode ficar confinado a ideia de um ofício sem saberes.

\subsection{De um Ofício sem Saberes à perspectiva de um Ofício feito de Saberes}

No âmbito desse processo, parafraseando Gauthier et al. (1998), poder-se-ia perguntar: para ensinar (a LI) basta ter: Talento?; Cultura?; Intuição?; Bom senso? Conhecimento do conteúdo?; Experiência?.

Os autores vão dizer que para ensinar há necessidade de se mesclar esse conjunto de características, afirmando também que o ensino tarda a refletir sobre si mesmo em seu próprio desenvolvimento. Nessa direção vão identificar três fases vinculadas a esse processo com os seguintes aspectos: um oficio sem saberes, saberes sem ofícios e um oficio feito de saberes.

\subsubsection{Um Ofício sem Saberes}

Arroyo (2000, p.18), buscando identificar o que caracteriza e distingue o trabalho do professor, explica que o termo ofício remete tanto a memória de um saber-fazer que carrega, quanto ao fato de se tratar de um fazer de artífice, qualificado, profissional, algo de que se tem orgulho, "a defesa de uma identidade individual e coletiva", pois, a "perícia dos mestres"' diz respeito às "artes de ensinar e educar" ao "saber acompanhar e conduzir a infância em seus processos de socialização, formação e aprendizagem". Para o autor, a educação que acontece nas escolas tem, ainda, muito de artesanal, no sentido positivo da palavra, dizendo que os seus mestres têm que ser artesãos, artífices, artistas para dar conta do magistério. Antonio Rugiu (1998) também vai dizer que neste tipo de oficio se aprende fazendo, envolvendo não apenas um saber-fazer, mas algo que vai além e que se configura como um dever-ser com fortes traços morais, 
éticos (ARROYO, 2000). Portanto, ser mestre, educador, é um modo de ser e um deverser (COELHO; DINIZ-PEREIRA, 2017).

Porém, Tenti Fanfani (2005, p. 263, tradução nossa) ao resgatar o termo professor, enquanto um ofício, vai na direção de sua etimologia de "obedecer a um chamado" e de se ter uma vocação:

[...] a vocação, assim como o sacerdócio, era uma qualidade inata, uma espécie de predisposição natural que os sujeitos têm ou não em maior ou menor medida. A vocação implicava um forte compromisso emocional e desinteressado com a atividade. A partir desta perspectiva, a docência era uma espécie de "dom" e por isso se associava mais a um"dever" e a uma "obrigação", do que a um trabalho em sentido estrito.

Mas tanto Arroyo quanto Tenti Fanfani criticam essa ideia de vocação atrelada à "imagem do mestre divino, evangélico, salvador", buscando ressignificar a noção de vocação no trabalho docente ao colocar que a «ideia de vocação pode estar incrustada na ideia de profissão" (ARROYO, 2000, p. 33) ou que "nada opõe a vocação à incorporação crescente de um conhecimento técnico-científico para a solução dos problemas de aprendizagem, que são cada vez mais complexos" (TENTI FANFANI, 2005, p. 268, tradução nossa).

Apesar dessas considerações, Tardif (2013), ao falar sobre as idades do ensino, focalizando a idade do ensino como vocação (século XVI - século XVII) vai colocar algumas noções vinculadas ao que foi dito, como dom, missão, chamamento espiritual, vocação, gostar de crianças etc., observando que a aprendizagem da docência ocorre pela observação de um mestre experiente e pela tentativa-erro. É claro que estar vocacionado pode ser importante, bem como gostar de crianças (seres humanos) deveria ser significativo, mas não pode ser a condição de entrada no magistério. Anteriormente, Tardif (2002), ao falar do ensino como arte, já tinha identificado alguns limites no qual essa formação teria como concepção o adulto em miniatura ou a ideia de tabula rasa em que se vai escrevendo as lições como no poema $A$ educação pela pedra, de João Cabral de Mello Neto (2005, p. 169):

Uma educação pela pedra: por lições; para aprender da pedra, frequentá-la; captar sua voz inenfática, impessoal (pela dicção ela começa as aulas).

A lição de moral, sua resistência fria ao que flui e a fluir; a ser maleada; a de poética, sua carnadura concreta; a de economia, seu adensar-se compacta; lições da pedra (de fora para dentro, cartilha muda), para quem soletra-la.

Nesse contexto, as contribuições de Arroyo (2000) e Tenti Fanfani (2005) podem ser significativas ao ressignificarem a concepção de ofício, mas podem não dar conta de superar uma aprendizagem artesanal. Assim sendo, relegar o ensino de LI, na Educação Infantil e no Ensino Fundamental I, apenas ao esforço dos professores, significa dizer que a docência se aprende fazendo, ocorre pela tentativa-erro.

Desse modo, como já foi colocado por Gauthier et al. (1998, p. 28) é claro que basear o ensino "no conhecimento do conteúdo, no bom senso, na experiência, na intuição, no talento ou numa vasta cultura não favorece de modo algum a formalização de saberes e de habilidades" específicas ao magistério, pois eles vêm "impedir, de forma perversa, a manifestação de saberes profissionais específicos, pois não relacionam a competência à posse de um saber próprio ao ensino", pois contribuem para deixar o professor "sapateando no mais estéril amadorismo."

Concluindo, se na mobilização dos saberes profissionais e análise de sua prática o professor não souber ressignificar os seus macetes, as suas rotinas e os seus esquemas de aula fundamentados no conhecimento científico, visando torná-los públicos, esse docente não será diferente de um leigo de boa vontade. 


\title{
4.2.2 Saberes sem Ofícios
}

Em função dos aspectos mencionados, Gauthier et al. (1998) colocam que ocorre uma fundação científica no ensino, na primeira metade do século $X X$, a partir da psicologia e da sociologia, podendo se incluir a esse rol a biologia e a administração, visando dar ao professor uma fundamentação aos problemas de sala de aula no que diz respeito aos escolares.

\begin{abstract}
E como se, fugindo de um mal para cair num outro, tivéssemos passado de um ofício sem saberes a saberes sem um ofício capaz de colocá-los em prática, saberes esses que podem ser pertinentes em si mesmos, mas nunca são reexaminados à luz do contexto real e complexo da sala de aula. É como se o saber científico sobre o ensino tivesse sido amputado de seu objeto real: um professor, numa sala de aula, diante de um grupo de alunos que ele deve instruir e educar de acordo com determinados valores. (GAUTHIER et al., 1998, p. 28).
\end{abstract}

Sobre o assunto, Charlot (2006) vai apontar que é comum encontrar discursos sobre a educação produzidos por disciplinas de ciências humanas, como a psicologia e a sociologia, podendo-se citar como exemplo o discurso construtivista. Na visão do autor esse foi um discurso que se desenvolveu no campo da educação, mas que se constituiu fora dela, pois dois dos seus teóricos - Piaget e Bachelard - não são pesquisadores em educação.

Tardif (2013) ao falar sobre os saberes sem oficio vai identificá-los como incrustados na idade do ensino como oficio (século XIX - século XX), considerando a formação das nações, o processo de secularização e de desconfessionalização das sociedades ocidentais marcadas também pela idade do trabalho.

\footnotetext{
Neste novo contexto social, a profissão de docente é gradualmente integrada a estruturas do Estado (nacional, federal, provincial, estatal, municipal, entre outras). Assim, a relação das professoras com o trabalho deixa gradualmente de ser vocacional, torna-se contratual e salarial. As professoras trabalham para construir uma carreira e obter um salário, ainda que a "mentalidade de serviço" continue presente. (...) Entretanto, como em qualquer profissão, a experiência concreta do trabalho permanece o cerne do saber ensinar. (TARDIF, 2013, p. 556-557).
}

Com a idade do ensino como ofício, há a necessidade do professor se formar e surgem as escolas normais. Nas "escolas normais, o aprendizado da profissão passa pela prática, pela imitação e pelo domínio das rotinas estabelecidas nas escolas pelas professoras experientes, bem como pelo respeito às regras escolares" (TARDIF, 2013, p. 557). De modo que, apesar dos avanços, a aprendizagem da docência continua, como pode ser visto, pela observação e imitação dos professores mais experientes, pela tentativa-erro e por um deve- ser.

Esta questão leva o autor a apresentar a seguinte provocação: "a idade do ofício continua seu curso. Devemos até mesmo nos perguntar se, no Brasil e, de forma mais ampla, na América Latina, o ensino atingiu plenamente a idade do ofício" (TARDIF, 2013, p. 558).

Parte da resposta se pode encontrar em Tenti Fanfani (2005, p. 265, tradução nossa) quando afirma que, em pesquisa sobre a condição docente em quatro países sul-americanos - Argentina, Brasil, Peru e Uruguai -, "os dados mostram que a grande maioria dos docentes considera a sua atividade como vocacional e profissional ao mesmo tempo" e "o que antes aparecia como oposto e contraditório, agora se apresenta de forma mais complexa e inter-relacionada." A outra parte da resposta se pode encontrar em Arroyo (2000, p. 37) ao colocar que "o imaginário social configurou o ofício de mestre com fortes traços morais, éticos. No terreno do dever" e que "sejam mais do que competentes" e em Tardif (2013) ao sublinhar que, dependendo do país ou região, a idade do ensino pode estar imbricada nas três idades ou localizada mais em uma 
idade do que em outra, adiando o processo de profissionalização e de desenvolvimento profissional dos professores.

\subsubsection{Um Ofício feito de Saberes}

Nesse contexto, Gauthier et al. (1998, p. 28-35) vão apresentar uma outra visão de ensino no qual o professor mobiliza um conjunto de saberes que formam uma espécie de reservatório, amalgama ou corpo de conhecimentos com os quais desenvolve a ação pedagógica. Não se trata mais de ir buscar em outras áreas ou de ficar no campo da habilidade, da intuição, da missão, do dom, do bom senso, da cultura ou mesmo da experiência. Trata-se de um corpo de saberes:

O saber disciplinar - os saberes disciplinares correspondem às diversas áreas de conhecimento, cabendo lembrar que o professor não produz esse saber, mas para ensinar extrai os saberes produzidos pelos pesquisadores, porque ensinar exige não só um conhecimento do conteúdo a ser ensinado, mas também a história e o contexto daquela disciplina; de modo que o tipo de conhecimento que o professor possui influencia no seu ensino e na aprendizagem dos alunos.

O saber curricular - uma disciplina nunca é ensinada da mesma forma que ela se apresenta, pois ela sofre transformações para entrar em um programa escolar, visando se tornar um programa de ensino. O professor deve conhecer esse programa que, geralmente, é montado por uma equipe de especialistas, cabendo a ele fazer as adequações necessárias e estabelecer critérios para que isto aconteça.

O saber das ciências da educação - os critérios utilizados pelos professores têm como fonte de informação determinados conhecimentos profissionais que foram adquiridos durante a sua formação, que embora possam não auxiliá-lo diretamente, contribuem informando-o sobre as várias faces de seu ofício e da educação de uma forma geral, como: noções sobre o desenvolvimento da criança e das classes sociais, o conhecimento da escola etc., permeando a maneira do professor existir profissionalmente.

O saber da tradição pedagógica - caracteriza-se no âmbito de uma tradição pedagógica que foi instalada no século XVII, na qual se estrutura com uma nova maneira de fazer a escola, onde o mestre deixa de dar aulas individualmente e passa a dar aulas para grupos de alunos, criando, assim, uma tradição pedagógica; porém, essa tradição chegou até os nossos dias, estando presente na cabeça de muitos alunos, por exemplo, na questão da aula em sua sequência, podendo incorporar muitos erros, bem como ser modificada pelo saber da experiência e ser validado ou não pelo saber da ação pedagógica.

O saber da experiência - a experiência e o hábito estão diretamente relacionados, pois se aprende a partir das próprias experiências, assim como a mesma pode se tornar a regra no desenvolvimento de rotinas. Mas, como essas rotinas acabam ficando confinadas na sala de aula, elas assumem uma perspectiva privada, pois a experiência do professor não deixa de ser algo pessoal. O professor, em seu trabalho docente, desenvolve julgamentos privados em uma espécie de jurisprudência composta de truques e estratagemas que permanecem em segredos e não são verificados por meio de métodos científicos. Portanto, o que limita o seu saber experiencial é que ele é feito de pressupostos e de argumentos que podem incorporar explicações errôneas para justificar a sua maneira de agir.

O saber da ação pedagógica - é o saber experiencial a partir do momento em que se tornou público por ter sido testado pelas pesquisas realizadas em sala de aula. Assim sendo, o saber da ação pedagógica nada mais é do que uma tentativa de se fundamentar os julgamentos que servem de apoio aos professores, a fim de estabelecer regras de ação que serão conhecidas e aprendidas por outros professores. De modo que eles são os saberes menos desenvolvidos pelos professores e os mais necessários no campo da profissionalização do ensino, pois não pode haver profissionalização do ensino enquanto esse saber não for explicitado. 
Na visão de Gauthier et al. (1998, p. 35) "para profissionalizar o ensino é essencial identificar os saberes da ação pedagógica válidos e levar os outros atores sociais a aceitar a pertinência desses saberes", de forma que a profissionalização do ensino tenha "não somente uma dimensão epistemológica, (...), mas também uma dimensão política, no que se refere a êxito de um grupo social em fazer com que a população aceite a exclusividade dos saberes e das práticas que ele detém."

Tardif (2013, p. 561), ao falar da idade do ensino como profissão (a partir da segunda metade do século XX...), coloca que o grande desafio que ela enfrenta "é fazer com que o ensino passe do estatuto de ofício para o de profissão em sua integralidade"; oferecer "uma formação universitária de alto nível"; desenvolver "competências profissionais baseadas em conhecimentos científicos" e passar de "uma visão rotineira da pedagogia a uma concepção", "do respeito às regras e rotinas escolares a uma ética profissional a serviço dos alunos e de seu aprendizado" e "do papel de funcionário ao de profissional autônomo, mas também imputável de suas escolhas, o que pede uma avaliação do ensino."

Assim sendo, observa-se que a Base Nacional Comum Curricular deixa em branco as orientações referentes ao ensino da LI na Educação Infantil e Ensino Fundamental I, lembrando-nos que para ensinar não basta ter experiência, bom senso, intuição, cultura ou conhecimento do conteúdo, levando-nos ao desafio do próximo ponto.

\subsection{A Base Nacional Comum Curricular como Proposta para Século XXI}

No século $X X I$, o ensino de LI para crianças no Brasil tem se tornado cada vez mais comum. A inclusão dessa língua estrangeira na matriz curricular da Educação Infantil e Anos Iniciais do Ensino Fundamental já é uma realidade, apesar do seu caráter facultativo e da necessidade de diretrizes oficiais nacionais que estabeleçam objetivos e norteiem o trabalho dos professores.

Uma vez que a oferta da disciplina, já consolidada na rede particular, encontra-se em expansão nas escolas públicas estaduais e municipais, consideramos a possibilidade da Base Nacional Comum Curricular, por ser um documento recente, fazer alguma referência ao ensino de línguas estrangeiras nesses níveis de ensino.

Entretanto, tanto a primeira versão do documento quanto sua versão final encaminhada ao CNE, analisadas neste trabalho, não discutem o referido ensino, perpetuando não só a lacuna existente, mas também a forma, nem sempre adequada, como o ensino vem sendo conduzido na ausência de diretrizes oficiais.

Essa questão já foi discutida no corpo deste texto, chegando-se a conclusão de que, por conta da globalização ou mundialização assim como dos intercâmbios culturais, a formação escolar, bem como universitária, no que diz respeito à língua, há muito tempo deixou de ser apenas uma formação local ou regional e ou ainda fechada na própria realidade do país. Assim, pensar em uma língua estrangeira não significa desconsiderar a língua oficial ou mesmo a própria riqueza linguística e cultural do país, mas significa ampliar as nossas fronteiras de diálogo com o conhecimento. Para além da globalização, como fenômeno econômico, deve-se superar os limites na direção a uma formação cultural mais ampla.

Concluindo, salientamos a necessidade de mais estudos na área, que, dentre outros aspectos, analisem a legislação referente à formação de professores, bem como os documentos que regulamentam a inclusão da LI para crianças nas esferas estadual e municipal. Mais do que simplesmente incluir disciplinas que tratem do ensino de línguas estrangeiras para crianças nos Cursos de Licenciatura em Letras, defendemos a criação de espaços para a discussão de problemas no âmbito da prática, bem como o investimento no desenvolvimento profissional docente, por meio de formações periódicas, pautadas em concepções colaborativas e participativas. Nessa perspectiva, o professor é protagonista e assume a responsabilidade pela própria formação. 


\section{REFERÊNCIAS}

ARROYO, M. G. Ofício de Mestre: imagens e auto-imagens. 7. ed. Petrópolis, RJ: Editora Vozes, 2000.

BAUMAN, Z. Vida líquida. Tradução C. A. Medeiros. Rio de Janeiro: Jorge Zahar Ed., 2007.

BRASIL. Constituição da República Federativa do Brasil de 1988. Diário Oficial da União, Brasília, DF, 5 out. 1988. Disponível em: <http://www.planalto.gov.br/ccivil_03/Constituicao/ Constituicao.htm>. Acesso em: 18 out. 2015.

Decreto $n^{\circ} 21.241$, de 4 de abril de 1932. Consolida as disposições sobre a organização do ensino secundário e dá outras providências. Diário Official, Rio de Janeiro, 9 abr. 1932. Disponível em: <http://www.histedbr.fe.unicamp.br/navegando/fontes_escritas/5_ Gov_Vargas/decreto\%2021.241-1932\%20reforma\%20francisco\%20campos.htm>. Acesso em: 16 out. 2015.

. Lei $n^{\circ}$ 4.024, de 20 de dezembro de 1961. Fixa as Diretrizes e Bases da Educação Nacional. Diário Oficial da União, Brasília, DF, 27 dez. 1961. Disponível em: <http://www2. camara.leg.br/legin/fed/lei/1960-1969/lei-4024-20-dezembro-1961-353722-normaatualizadapl.pdf>. Acesso em: 14 out. 2015.

. Lei $n^{\circ} 5.692$, de 11 de agosto de 1971. Fixa Diretrizes e Bases para o ensino de $1^{\circ}$

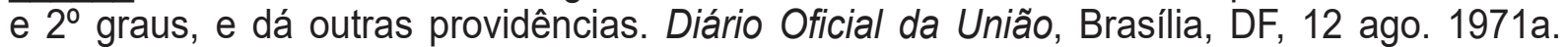
Disponível em: <http://educacao.salvador.ba.gov.br/site/documentos/espaco-virtual/espacolegislacao/EDUCACIONAL/NACIONAL/Idb\%20n\% C2\%BA\%205692-1971.pdf>. Acesso em: 14 out. 2015.

. Lei $n^{\circ}$ 9.394, de 20 de dezembro de 1996. Estabelece as diretrizes e bases da educação nacional. Diário Oficial da União, Brasília, DF, 23 dez. 1996. Disponível em: <http:// www.planalto.gov.br/ccivil_03/Leis/L9394.htm>. Acesso em: 14 out. 2015.

. Parecer CEF no 853, de 12 de novembro de 1971. Núcleo-comum para os currículos do ensino $\overline{\text { de } 1^{\circ} \text { e }} 2^{\circ}$ graus. A doutrina do currículo na Lei n. 5.692. Documenta $n^{\circ} 132$, Rio de Janeiro, nov. 1971b. Disponível em: <http://www.histedbr.fe.unicamp.br/navegando/fontes_escritas/7_Gov_Militar/ parecer\%20n.\%20853-1971\%20n\%FAcleo\%2 0comum\%20para\%20os\% $\overline{2} 0$ curr\%EDculos....pdf>. Acesso em: 15 out. 2015.

Resolução CEF n 58, de 22 de dezembro de 1976. Altera dispositivos da Resolução nº 8 , de $1^{\circ}$ de dezembro de 1971, e dá outras providências. Documenta $n^{\circ}$ 193, Rio de Janeiro, dez. 1976. Disponível em: <http://www.histedbr.fe.unicamp.br/navegando/fontes_escritas/7_Gov_Militar/ resolu $\%$ E7\%E3o\%20n.58-1976\%20altera\%20dispositivos\%20da $\% 20$ resolu $\% \bar{E} 7 \%$ E3o\% $\overline{2} 0$ n. $\% 208$. pdf $>$. Acesso em: 18 out. 2015.

Ministério da Educação. Base Nacional Comum Curricular. Brasília, DF: MEC, [201-]a. Disponível em: <http://basenacionalcomum.mec.gov.br/documento/BNCC-APRESENTACAO.pdf $>$. Acesso em: 17 out. 2015.

Ministério da Educação. Base Nacional Comum Curricular. Brasília, DF: MEC, 2017. Disponível em: http://basenacionalcomum.mec.gov.br/images/BNCC_publicacao.pdf. Acesso em: 01 jun. 2017.

. Ministério da Educação. Base Nacional Comum Curricular. Histórico. Brasília, DF: MEC,

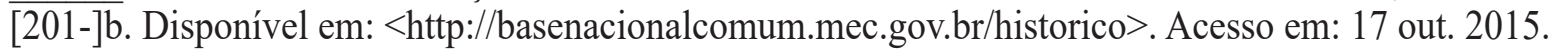

. Ministério da Educação. Secretaria de Educação Básica. Diretrizes curriculares nacionais para

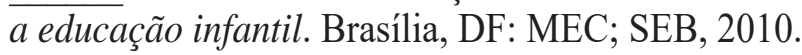


BRAVO, R. S. Técnicas de investigação social: teoria e ejercicios. 7. ed. Madrid-ES: Paraninfo, 1991.

CALADO, S. dos S.; FERREIRA, S. C. dos R. Análise de documentos: método de recolha e análise de dados. Lisboa-PT: DEFCUL, 2004. Disponível em: <http://www.educ.fc.ul.pt/ docentes/ichagas/mi1/analisedocumentos.pdf.>. Acesso em: 18 mar. 2019.

CHARLOT, B. A pesquisa educacional entre conhecimentos, políticas e práticas: especificidades e desafios de uma área de saber. Revista Brasileira de Educação, v. 11, n. 31, jan./abr. 2006.

COELHO, A. M. S.; DINIS-PEREIRA, J. E. Olhar o magistério "no próprio espelho": o conceito de profissionalidade e as possibilidades de se repensar o sentido da profissão docente. Revista Portuguesa de Educação, Minho-PT, v. 30, n. 1, p. 7-34, 2017.

COSTA, L. P. Uso de um exame internacional de proficiência em língua inglesa para crianças no ensino fundamental brasileiro. 2009. Dissertação (Mestrado em Linguística Aplicada)Instituto de Estudos da Linguagem, Universidade Estadual de Campinas, Campinas, 2009.

GAUTHIER, C. et al. Por uma teoria da pedagogia: pesquisas contemporâneas sobre o saber docente. Ijuí/Rs: UNIJUì, 1998.

GILENO, R. S. da S. O ensino das línguas estrangeiras no Brasil: uma perspectiva históricometodológica. In: MONTEIRO, D. C.; NASCENTE, R. M. M. (Org.). Pesquisa, ensino e aprendizagem da língua inglesa: olhares e possibilidades. São Paulo: Cultura Acadêmica, 2013.

GOERGEN, P. A educação como direito de cidadania e responsabilidade do Estado. Educação \& Sociedade, Campinas, n. 124, p. 723-742, 2013.

GOMES, R. Análise e interpretação de dados de pesquisa qualitativa. In: DESLANDES, S. F.; GOMES, R.; MINAYO, M. C. S.(Org.). Pesquisa social: teoria, método e criatividade. 26. ed. Petrópolis, RJ: Vozes, 2007. p. 79-108.

LEFFA, V. J. Aspectos políticos da formação do professor de línguas estrangeiras. In:

(Org.). O professor de línguas estrangeiras: construindo a profissão. Pelotas-RS: $\overline{\text { Educat}}$, 2001. p. 333-355. v. 1.

O ensino de línguas estrangeiras no contexto nacional. CONTEXTURAS: Ensino Crítico de Língua Inglesa, São Paulo, n. 4, p. 13-24, 1998.

LE GOFF, J. História e memória: criação de espaços para a discussão de problemas da prática. Tradução Bernardo Leitão et al. Campinas-SP: Ed. Unicamp, 1996.

LIMA, D. M. de A. O processo de aquisição de língua estrangeira por crianças brasileiras em sala de aula: reflexões sobre a teoria de Krashen. In: MONTEIRO, D. C. (Org.). Ensinoaprendizagem de Língua Inglesa em alguns contextos brasileiros. São Paulo: Cultura Acadêmica Editora, 2004. p. 35-69.

LINGUEVIS, M. L. Vamos ouvir a voz das crianças sobre aprender inglês na educação infantil! In: TONELLI, J. R. A.; RAMOS, S. G. M (Org.). O ensino de LE para crianças: reflexões e contribuições. Londrina-PR: Moriá, 2007. p. 137-154.

LOPES, L. P. da M. Inglês e globalização em uma epistemologia de fronteira: ideologia lingüística para tempos híbridos. DELTA: Documentação de Estudos em Lingüística Teórica e Aplicada, São Paulo, v. 24, n. 2, p. 309-340, 2008. 
Inglês no mundo contemporâneo: ampliando oportunidades sociais por meio da educação. São Paulo, 2005. Texto-base do Simpósio da TIRF (TESOL International Research Foundation). Mimeografado.

MELLO NETO, J. C. Education by stone: selected poems. Tradução Richard Zenith. New York: Archipelago Books, 2005.

MITROVITCH, C. Experiência e formação em Walter Benjamin. São Paulo: Editora UNESP, 2011.

NÓVOA, A. Formação de professores e profissão docente. In: (Coord.). Os professores e a sua formação. Lisboa-PT: Publicações Dom Quixote, 1992. p. 13-33.

Os professores na virada do milênio: do excesso dos discursos à pobreza das práticas. Educação e Pesquisa, v. 25, n. 1, p. 11-20, 1999.

PIRES, S. S. Ensino de inglês na Educação Infantil. In: SARMENTO, S.; MÜLLER, V. (Org.). O ensino do inglês como língua estrangeira: estudos e reflexões. Porto Alegre: APIRS, 2004. p. $19-42$.

RAJAGOPALAN, K. O inglês como língua internacional na prática docente. In: LIMA, D. C. (Org.). Ensino e aprendizagem de Língua Inglesa: conversas com especialistas. São Paulo: Parábola Editoria, 2009. p. 39-46.

RAMOS, S. G. M. A internet e suas contribuições ao ensino de inglês para crianças. In: TONELLI, J. R. A.; RAMOS, S. G. M. (Org.). O ensino de LE para crianças: reflexões e contribuições. Londrina-PR: Moriá, 2007. p. 61-75.

RIO CLARO. Resolução SME n 002, de 30 de janeiro de 2013. Estabelece diretrizes para a organização curricular da educação infantil e do ensino fundamental nas escolas da Rede Municipal de Ensino de Rio Claro para o ano letivo de 2013. Secretaria Municipal da Educação, Rio Claro, 30 jan. 2013. Disponível em: <http://www.educacaorc.com.br/media/ biblioteca/7000453/matrizcurricular.pdf>. Acesso em: 20 out. 2015.

RIO CLARO. Resolução SME n 006, de 06 de fevereiro de 2014. Estabelece diretrizes para a organização curricular da educação infantil e do ensino fundamental nas escolas da Rede Municipal de Ensino de Rio Claro para o ano letivo de 2014. Secretaria Municipal da Educação, Rio Claro, 06 fev. 2014. Disponível em: <http://www.educacaorc.com.br/media/ biblioteca/7000748/Resolu\% C3\%A7\%C3\%A3o006_MatrizCurricular.pdf>. Acesso em: 20 out. 2015.

RIO CLARO. Resolução SME n 006, de 03 de março de 2015. Estabelece diretrizes para a organização curricular da educação infantil e do ensino fundamental nas escolas da Rede Municipal de Ensino de Rio Claro para o ano letivo de 2015. Secretaria Municipal da Educação, Rio Claro, 03 mar. 2015. Disponível em: <http://www.educacaorc.com.brl media/biblioteca/7001203/ Resolu\%C3\%A7\%C3\%A30\%20SME\%20006-2015\%20\%20 Organiza\%C3\%A7\%C3\%A30\%20Curricular. PDF>. Acesso em: 20 out. 2015.

ROCHA, C. H. O ensino de LE (inglês) para crianças do ensino fundamental público na transdisciplinaridade da linguística aplicada. In: TONELLI, J. R. A.; RAMOS, S. G. M. (Org.). O ensino de LE para crianças: reflexões e contribuições. Londrina-PR: Moriá, 2007. p. 1-34.

. O ensino de línguas para crianças: refletindo sobre princípios e práticas. In: ROCHA, C. H.; BASSO, E. A. (Org.). Ensinar e aprender língua estrangeira nas diferentes idades: reflexões para professores e formadores. São Carlos-SP: Claraluz, 2008. p. 15-34. 
. Provisões para ensinar LE no ensino fundamental de $1^{a}$ a $4^{a}$ séries: dos parâmetros oficiais e objetivos dos agentes. 2006. Dissertação (Mestrado em Linguística Aplicada)Instituto de Estudos da Linguagem, Universidade Estadual de Campinas, Campinas, 2006.

SÃO PAULO. Resolução SE n 29 , de 28 de maio de 2014. Institui o Projeto Early Bird - Língua Inglesa destinado a alunos dos anos iniciais do Ensino Fundamental das Escolas Estaduais. Diário Oficial do Estado de São Paulo, São Paulo, 28 maio 2014. Disponível em: <http://siau. edunet.sp.gov.br/ItemLise/arquivos/29_14.HTM?Time=22/02/2015\%2008:28:35>. Acesso em: 17 fev. 2015.

SCARAMUCCI, M. V. R.; COSTA, L. P.; ROCHA, C. H. A avaliação no ensino-aprendizagem de línguas para crianças: conceitos e práticas. In: ROCHA, C. H.; BASSO, E. A. (Org.). Ensinar e aprender língua estrangeira nas diferentes idades: reflexões para professores e formadores. São Carlos-SP: Claraluz, 2008. p. 85-112.

SCHEIFER, C. L. Ensino de língua estrangeira para crianças: entre "o todo" e "a parte": uma análise da dinâmica das crenças de uma professora e de seus alunos. 2008. Dissertação (Mestrado em Letras)- Universidade Católica de Pelotas, Pelotas-RS, 2008.

SILVA, L. R. C. et al. Pesquisa documental: alternativa investigativa na formação docente. In: CONGRESSO NACIONAL DE EDUCAÇÃO, 9.; ENCONTRO SUL BRASILEIRO DE PSICOPEDAGOGIA, 3., 2009, Curitiba. Anais... Curitiba: PUCPR, 2009. p. 4554-4566.

TARDIF, M. A profissionalização do ensino passados trinta anos: dois passos para a frente, três para trás. Educação \& Sociedade, Campinas, v. 34, n. 123, p. 551-571, jun. 2013. Disponível em: <http://www.scielo.br>. Acesso: 28 ago. 2013.

. Saberes docentes e formação profissional. Petrópolis-RJ: Editora Vozes, 2002.

TENTI FANFANI, E. La condición docente: análisis comparado de la Argentina, Brasil, Perú y Uruguai. Buenos Aires: Siglo XXI Editores, 2005.

TONELLI, J. R. A.; CRISTOVÃO, V. L. L. O papel dos cursos de Letras na formação de professores de inglês para crianças. Calidoscópio, v. 8, n. 1, p. 65-76, jan./abr. 2010.

VIDOTTI, J. J. V. Políticas linguísticas para o ensino de língua estrangeira no Brasil do século $X I X$, com ênfase na língua inglesa. 2012. 245 f. Tese (Doutorado em Letras)- Faculdade de Filosofia, Letras e Ciências Humanas, Universidade de São Paulo, São Paulo, 2012. 